CURATIVE VIOLENCE 
This page intentionally left blank 


\section{CURATIVE VIOLENCE}

Rehabilitating Disability, Gender,

and Sexuality in Modern Korea

EUNJUNG KIM

DUKE UNIVERSITY PRESS

Durham and London

2017 
(C) 2017 Duke University Press

All rights reserved

Printed in the United States of America

on acid-free paper $\infty$

Typeset in Minion Pro by Copperline

Library of Congress Cataloging-in-Publication Data

Names: Kim, Eunjung, [date] author.

Title: Curative violence : rehabilitating disability, gender, and sexuality in modern Korea / Eunjung Kim.

Description: Durham : Duke University Press, 2016.|

Includes bibliographical references and index.

Identifiers: LCCN 2016026987 (print)

LCCN 2016028135 (ebook)

ISBN 9780822362777 (hardcover : alk. paper)

ISBN 9780822362883 (pbk. : alk. paper)

ISBN 9780822373513 (e-book)

Subjects: LCSH: People with disabilities-Care-Korea

(South) | People with disabilities-Rehabilitation-Korea

(South) | Sociology of disability_Korea (South) | People with disabilities in mass media.

Classification: LCC HV1559.K8 K54 2016 (print) |

LCC HV1559.K8 (ebook) | DDC 362.4095195-dc23

LC record available at https://lccn.loc.gov/2016026987

Cover art: Jiwon, Daily Happenings (details), 2005.

Acrylic on canvas. Courtesy of the artist. 